\title{
Seroprevalence of Toxoplasma gondii, Neospora caninum, and Leishmania spp. in hunting dogs from Mato Grosso do Sul, Brazil
}

\author{
Silvana Marques Caramalac ${ }^{1}$ Sid Simone Marques Caramalac $^{1}$ (i) Pablo Menegon Castilho ${ }^{2}$ (i) \\ Juliana Izidoro Lucas $^{2}$ (1) Ana Flávia Minutti ${ }^{2}$ (i) João Luis Garcia ${ }^{2}$ (D) Luiz Daniel de Barros $^{2^{*}}$ (D) \\ Mariana Isa Poci Palumbo ${ }^{1}$ (D)
}

${ }^{1}$ Faculdade de Medicina Veterinária, Universidade Federal de Mato Grosso do Sul (UFMS), Campo Grande, MS, Brasil.

${ }^{2}$ Departamento de Medicina Veterinária Preventiva, Universidade Estadual de Londrina (UEL), 86057-970, Londrina, PR, Brasil. E-mail: daniel_vetuel@hotmail. "Corresponding author.

ABSTRACT: Toxoplasmosis, neosporosis, and leishmaniasis are important diseases of worldwide distribution and can affect both pets and humans. Hunting dogs have been trained to hunt domestic and wild animals, which makes them more exposed to parasitic infections. The present study aimed to evaluate the seroprevalence of Toxoplasma gondii, Neospora caninum, and Leishmania spp. in hunting dogs from a rural area in Mato Grosso do Sul, Brazil. Serum samples were collected from 39 American Foxhound dogs, and the sex and age variables were recorded. Serum samples were subjected to an indirect fluorescent antibody test (IFAT) to detect antibodies. Seroprevalence was 35.9\%, $15.4 \%$, and 2.6\% for Toxoplasma gondii, Neospora caninum e Leishmania spp., respectively. There was no statistical difference between genders for these diseases $(P>0.05)$. Results demonstrated a circulation of these protozoa in hunting dogs in a rural area of the state of Mato Grosso do Sul, which can contribute to the epidemiology of these diseases.

Key words: Toxoplasma gondii, Neospora caninum, Leishmania spp., IFAT.

Soroprevalência de Toxoplasma gondii, Neospora caninum e Leishmania spp. em cães de caça do Mato Grosso do Sul, Brasil

RESUMO: Toxoplasmose, neosporose e leishmaniose são importantes doenças de distribuição mundial e podem afetar tanto os animais de companhia quanto os humanos. Os cães de caça têm sido treinados para caçar animais domésticos e selvagens, o que torna esses animais mais expostos a infecções parasitárias. O presente estudo teve como objetivo avaliar a soroprevalência de Toxoplasma gondii, Neospora caninum e Leishmania spp. em cães de caça de área rural do Mato Grosso do Sul, Brasil. Foram coletadas amostras de soro de 39 cães da raça Foxhound-americano e as variáveis sexo e idade foram registradas. As amostras de soro foram submetidas a reação de imunofluorescência indireta (RIFI) para detecção dos anticorpos. A soroprevalência foi de 35,9\%, 15,4\% e 2,6\% para Toxoplasma gondii, Neospora caninum e Leishmania spp., respectivamente. Não foi observado diferença estatística entre os sexos para todas as doenças (P>0.05). Os resultados demonstram circulação desses protozoários em cães de caça de uma área rural do estado do Mato Grosso do Sul, o que pode contribuir para a epidemiologia dessas doenças.

Palavras-chave: Toxoplasma gondii, Neospora caninum, Leishmania spp., RIFI.

\section{INTRODUCTION}

Toxoplasma gondii, Neospora caninum, and Leishmania spp. are important infectious agents caused by obligate intracellular protozoa (JOOB \& WIWANITKIT, 2019), which lead to the manifestation of several clinical symptoms (ANVARI et al., 2020) and can affect several species of mammals, including humans. In a recent study, $N$. caninum DNA was detected in umbilical cord blood samples from pregnant women, indicating human exposure to the parasite; however, the zoonotic potential remains unclear (DUARTE et al., 2020). Seroprevalence studies in dogs are essential indicators of disease in regions, since, in addition to participating in the chain of disease transmission to humans and other animals, they can act as carriers and sentinels of these diseases.

The presence of dogs on the farms is common since they assist in handling livestock or are pets for the workers from the farm. As T. gondii and $N$. caninum frequently affect wild and farm animals, dogs on farms are much more susceptible to these 
agents than those that live in urban environments (SÁNCHEZ et al., 2003; SORTE et al., 2015). In addition, dogs may be responsible for transmitting diseases to humans that primarily affect wild animals due to close contact with their owners and possible mechanical transmission of oocysts (LINDSAY et al., 1997; ORR et al., 2019).

In leishmaniasis, the dog acts in the transmission cycle as the main reservoir, transmitting the parasite to humans by the Lutzomyia and Phlebotomus sandflies (MATTOS JR et al., 2004). Moreover, the transmission of Leishmania between dogs can occur by the vertical (transplacental) or horizontal (venereal and blood transfusion) routes (DE FREITAS et al., 2006; NAUCKE \& LORENTZ, 2012). The disease is originally from the wild and rural areas and has become endemic in the urban area, mainly due to socio-environmental changes, deforestation, and urban development (BARATA et al., 2005).

Currently, these three diseases are present in dogs in the urban area of Campo Grande, in Brazil; however, there are no published studies regarding their prevalence in animals from rural areas in this region. Thus, this study aimed to determine the prevalence of antibodies against $T$. gondii, N. caninum and, Leishmania spp. and investigate whether there is a difference in seroprevalence between genders and age in hunting dogs from Mato Grosso do Sul, Brazil.

\section{MATERIALS AND METHODS}

\section{Sampling and animals}

American foxhound dogs that performed illegal hunting of jaguars and lived on a farm, located at $40 \mathrm{~km}$ from the urban area of the municipality of Campo Grande, Mato Grosso do Sul state, Brazil, were used in this study. All dogs were rescued from illegal center training for hunting. Blood samples were collected by puncture of the jugular vein using siliconized vacuum tubes without anticoagulant. The samples were subjected to centrifugation at $3000 \mathrm{~g}$ for 5 minutes to retract the clot, and the obtained serum was stored at $-20{ }^{\circ} \mathrm{C}$ until further analysis. All animals were subjected to physical examination to evaluate clinical changes as temperature, mucous color, hydration, and cardiorespiratory parameters.

\section{Indirect fluorescent antibody test (IFAT)}

Serum samples from dogs were evaluated by IFAT according to the methodology previously described (CAMARGO, 1973). The antigens for IFAT slides were the tachyzoites of RH strain for T. gondii, $\mathrm{NC1}$-strain for N. caninum, and the promastigote of
L. infantum. The fluorescein isothiocyanate (FITC)labeled anti-dog IgG (Sigma-Aldrich, USA) was used as a secondary antibody. Serum samples from dogs known to be positive and negative obtained from our serum bank were included in all slides. Only samples that present fluorescence over the total contour of the parasite were considered positive. The cut-off for T. gondii, $N$. caninum, and Leishmania. spp. were 64, 50, and 40, respectively. Positive samples were titrated until the maximum dilution titer was reached.

\section{Statistical analysis}

The variables age (young: $<1$ year; adult: 1-7 years; older: $>7$ years) and gender were analyzed by Fisher's exact test using the BioEstat 5.0 program. $\mathrm{P}$-value $\leq 0.05$ was considered significant.

\section{RESULTS AND DISCUSSION}

Of the 39 dogs analyzed, 14 (35.9\%) were positive for $T$. gondii, with titers of $64(64.3 \%), 256$ (21.5\%), $1024(7.1 \%)$ and $4096(7.1 \%)$. Females showed higher titers compared to males; however, no statistical differences were observed according to gender and age $(\mathrm{P}>0.05)$ (Table 1). Only one dog was seropositive for Leishmania spp. (2.6\%), and this dog was co-infected with $T$. gondii. No clinical signs of infection were observed in any of the animals, including the absence of lymph node enlargement and dermatopathies.

For N. caninum, $6(15.4 \%)$ dogs were positive, with titers ranging from $50(16 \%), 100$ (16\%), $200(16 \%)$, and 400 (48\%). There were also no differences between sex or age $(\mathrm{P}>0.05)$ (Table 1). Although the seroprevalence between $T$. gondii and $N$. caninum was different in absolute numbers, there was no statistical difference between the positive cases for both parasites $(\mathrm{P}=0.069)$.

Out of all animals in this study, 17 (43.6\%) were seropositive for at least one of the parasites, and co-infection was observed in three animals (7.7\%), two with $T$. gondii and $N$. caninum and the other with T. gondii and Leishmania spp., as reported before. Due to the low seroprevalence of leishmaniasis in the dogs from our study, it was impossible to establish whether there is a correlation with the other parasites. However, ANDREOTTI et al. (2006) founded no correlation between $N$. caninum and Leishmania infantum seroprevalence in dogs from Campo Grande. It showed that leishmaniasis does not cause higher susceptibility to $N$. caninum infection in dogs from this region. 
Table 1 - Results of indirect fluorescent antibody test (IFAT) for Toxoplasma gondii and Neospora caninum in hunting dogs from Mato Grosso do Sul, Brazil.

\begin{tabular}{|c|c|c|c|}
\hline \multirow[t]{2}{*}{ Variables } & \multicolumn{2}{|c|}{ 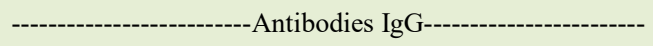 } & \multirow[t]{2}{*}{ P-value } \\
\hline & Positive & Negative & \\
\hline 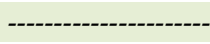 & Toxo & 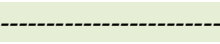 & $----\cdot$ \\
\hline \multicolumn{4}{|l|}{ Gender } \\
\hline Male & 7 & 17 & \multirow{2}{*}{0.44} \\
\hline Female & 7 & 8 & \\
\hline \multicolumn{3}{|l|}{ 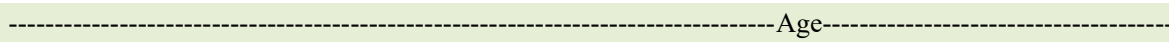 } & \multirow{2}{*}{ - } \\
\hline Young $(<1$ year $)$ & 0 & 4 & \\
\hline Adult (1-7 years) & 13 & 21 & 0.27 \\
\hline Older ( $>7$ years) & 1 & 0 & \multirow[t]{2}{*}{0.2} \\
\hline --------------------- & $--\mathrm{NeO}$ & ------------------------- & \\
\hline \multicolumn{3}{|l|}{ Gender } & \multirow{4}{*}{0.37} \\
\hline Male & 5 & 19 & \\
\hline Female & 1 & 14 & \\
\hline \multicolumn{3}{|c|}{ 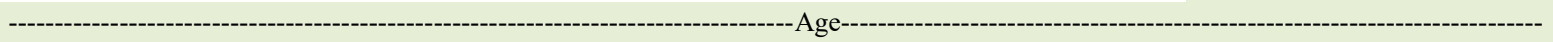 } & \\
\hline Young $(<1$ year $)$ & 0 & 4 & - \\
\hline Adult (1-7 years) & 5 & 29 & 1.0 \\
\hline Older ( $>7$ years) & 1 & 0 & 0.2 \\
\hline
\end{tabular}

According to results, a higher seroprevalence of $T$. gondii was observed in hunting dogs from Mato Grosso do Sul compared to $N$. caninum and Leishmania spp. The dogs were trained to practice illegal hunting of jaguars in the Cerrado and Pantanal region, which could explain this high seroprevalence of toxoplasmosis, since a previous study showed $100 \%$ of seropositivity for $T$. gondii in jaguars from these regions, evidencing the importance of this species in maintaining the parasite in nature (FURTADO et al., 2015). Different studies have shown a higher seroprevalence of $T$. gondii and $N$. caninum in hunting dogs than domiciliated dogs (AYINMODE et al. 2016; MACHACOVA et al., 2016; MACHADO et al., 2019; ORR et al., 2019). It occurs probably because hunting dogs have free access to water and food, which could be contaminated with oocysts and tissue cysts (AYINMODE et al., 2016). The prevalence of anti-T. gondii antibodies observed in this study was lower than studies with hunting dogs from southern Spain and northern Africa (CANOTERRIZA et al., 2016); however, it was higher from hunting dogs from Nigeria (AYINMODE et al., 2016) and Italy (MACHACOVA et al., 2016). Differences in geographical regions, serological tests, and cut-off can explain the variability of these results (ANVARI et al., 2020).

These factors could also explain the different results of the seroprevalence of $N$. caninum in hunting dogs (AYINMODE et al., 2016; COLLANTES-FERNANDEZ et al., 2008; MACHACOVA et al., 2016). However, the seroprevalence observed in this study is similar to the average seroprevalence in domestic dogs of the American continent between 1990-2018 (15.2\%) (ANVARI et al., 2020). The studied dogs lived in the rural region, and may play an important role in the transmission of $N$. caninum between wild animals and cattle, since different studies showed that dogs living in rural properties have a high prevalence of neosporosis, maybe due to close contact with wild animals, which are intermediate hosts for this protozoan (CANO-TERRIZA et al., 2016; AYINMODE et al., 2016; MACHACOVA et al., 2016; COLLANTES-FERNANDEZ et al., 2008).

A higher seroprevalence of $T$. gondii than $N$. caninum, as observed in this study, was also reported by AYINMODE et al. (2016) and MACHACOVA et al. (2016), demonstrating a greater environmental spread of these parasites in rural areas. Besides, there was no difference between $T$. gondii and $N$. caninum regarding gender, as same reported in previous studies in hunting (AYINMODE et al., 2016, CANOTERRIZA et al., 2016, COLLANTES-FERNANDEZ et al., 2008, MACHACOVA et al., 2016, MACHADO et al., 2019) and pet dogs (CABRAL et al., 1998, DA PAZ et al., 2019, GARCIA et al., 1999) showing that there is no higher predisposition to seroconversion 
according to gender. There also was no statistical difference in the seroprevalence of $T$. gondii and $N$. caninum between the age. Previous studies have reported a higher seroprevalence in older dogs, which is attributed to the significant cumulative exposure of dogs to this agent in the environment (CANOTERRIZA et al., 2016, MACHACOVA et al., 2016, MACHADO et al., 2019).

Only one dog had antibodies against Leishmania spp., which demonstrates the low prevalence of leishmaniasis in the rural area of Campo Grande. However, the disease is endemic in Campo Grande, which there are vector and positive dogs detection in all regions of the urban area (BRAZUNA et al., 2012). BOTELHO \& NATAL (2009) verified that $99 \%$ of the cases of human visceral leishmaniasis was in the urban area, $0.3 \%$ in a rural area, $0.2 \%$ in an urban/rural area, and $0.5 \%$ in an unknown area, demonstrating thus, a change in the pattern of transmission of the disease in Brazil, with a predominance of transmission in urban areas. A previous study has been shown a high seroprevalence of Leishmania in dogs from Campo Grande, with a higher rate of co-infection with $N$. caninum. It evidences the importance of dogs in maintaining both parasites in the urban area (ANDREOTTI et al., 2006). In Mato Grosso, dogs from urban areas had a risk of infection three times higher than dogs from rural areas. It could be related to the recent urbanization, which could create favorable conditions for the development of the vector (LOPES et al., 2014).

\section{CONCLUSION}

The results showed the seroprevalence of T. gondii, N. caninum, and Leishmania spp. in hunting dogs from Mato Grosso do Sul, Brazil. Moreover, due to the close contact with wild and farm animals, hunting dogs could represent a source of infection to domestic animals and humans, which could be contributing to the epidemiology of the diseases.

\section{ACKNOWLEDGMENTS}

This study was financed in part by the Coordenação de Aperfeiçoamento de Pessoal de Nível Superior - Brasil (CAPES) - Finance code 001. J.L. Garcia is recipient of Conselho Nacional de Desenvolvimento Científico e Tecnológico (CNPq) fellowship.

\section{BIOETHICS AND BIOSSECURITY COMMITTEE APPROVAL}

The present study was approved by the Animal Ethical Committee of the Universidade Federal do Mato Grosso do Sul ( ${ }^{\circ}$ $1.104 / 2019)$.

\section{DECLARATION OF CONFLICT OF INTERESTS}

The authors declare no conflict of interest. The founding sponsors had no role in the design of the study; in the collection, analyses, or interpretation of data; in the writing of the manuscript, and in the decision to publish the results.

\section{AUTHORS' CONTRIBUTIONS}

The authors contributed equally to the manuscript.

\section{REFERENCES}

ANDREOTTI, R.. et al. Occurrence of Neospora caninum in dogs and its correlation with visceral leishmaniasis in the urban area of Campo Grande, Mato Grosso do Sul, Brazil. Veterinary Parasitology, v.135, n.3-4, p.375-379, 2006. Available from: $<$ https://www.sciencedirect.com/science/article/abs/pii/ S0304401705004954https://www.sciencedirect.com/science/ article/abs/pii/S0304401705004954>. Accessed: Jun. 23, 2019. doi: 10.1016/j.vetpar.2005.10.011.

ANVARI, D. et al. Seroprevalence of Neospora caninum infection in dog population worldwide: a systematic review and metaanalysis. Acta Parasitologica, p.1-18, 2020. Available from: $<$ https://link.springer.com/article/10.2478/s11686-019-00163-4>. Accessed: Jun. 23, 2019. doi: 10.2478/s11686-019-00163-4.

AYINMODE, A. B. et al. Seroprevalence of Toxoplasma gondii and Neospora caninum in urban and rural dogs from southwestern Nigeria. African Journal of Infectious Diseases, v.10, n.1, p.2528, 2016. Available from: <https:/www.ajol.info//index.php/ajid/ article/view/126763>. Accessed: Jun. 23, 2019. doi: 10.4314/ajid. v10i1.5.

BARATA, R.A. et al. Aspects of the ecology and behaviour of phlebotomines in endemic area for visceral leishmaniasis in State of Minas Gerais. Revista da Sociedade Brasileira de Medicina Tropical, v.38, n.5, p.421-425, 2005. Available from: $<$ https://www.scielo.br/scielo.php?script=sci arttext\&pid=S003786822005000500012\&lng=pt\&tlng=pt $>$. Accessed: Jun. 23, 2019. doi: $10.1590 / \mathrm{S} 0037-86822005000500012$.

BOTELHO, A. C. A.; NATAL, D. First epidemiological description of visceral leishmaniasis in Campo Grande, State of Mato Grosso do Sul. Revista da Sociedade Brasileira de Medicina Tropical, v.42, n.5, p.503-508, 2009. Available from: $<$ https://www.scielo.br/scielo.php?script=sci_arttext\&pid=S0037$86822009000500006 \& \operatorname{lng}=p t \& t \operatorname{lng}=p t>$. Accessed: Jun. 23, 2019. doi: $10.1590 / \mathrm{S} 0037-86822009000500006$.

BRAZUNA, J. C. M. et al. Profile and geographic distribution of reported cases of visceral leishmaniasis in Campo Grande, State of Mato Grosso do Sul, Brazil, from 2002 to 2009. Revista da Sociedade Brasileira de Medicina Tropical, v.45, n.5, p.601-606, 2012. Available from: $<$ https://www.scielo.br/scielo.php?script=sci_ arttext\&pid=S0037-86822012000500012\&lng=en\&tlng=en $>$. Accessed: Jun. 23, 2019. doi: 10.1590/S0037-86822012000500012.

CABRAL, D. D. et al., Frequency of anti-Toxoplasma gondii antibodies in apparently healthy dogs of the city of Uberlândia MG. Revista Brasileira de Parasitologia Veterinária, v.7, p.8790, 1998. 
CAMARGO M. Introdução às técnicas de imunofluorescência. Revista Brasileira de Patologia Clinica, v.10, p.143-171, 1973.

CANO-TERRIZA, D. et al. Risk factors of Toxoplasma gondii infection in hunting, pet and watchdogs from southern Spain and northern Africa . Parasitology International, v.65, p.363-366, 2016. Available from: $<$ https://www.sciencedirect.com/science/ article/abs/pii/S1383576916300356?via\%3Dihub>. Accessed: Jun. 23, 2019. doi: 10.1016/j.parint.2016.05.001.

COLLANTES-FERNÁNDEZ E. et al. Seroprevalence and risk factors associated with Neospora caninum infection in different dog populations in Spain. Veterinary Parasitology, v.152, n.12, p.148-151, 2008. Available from: <https://www.sciencedirect. com/science/article/abs/pii/S0304401707006590?via\%3Dihub $>$. Accessed: Jun. 23, 2019. doi: 10.1016/j.vetpar.2007.12.005.

DA PAZ, G. S. et al. Infection by Toxoplasma gondii, Neospora caninum, Leishmania major and Trypanosoma cruzi in dogs from the state of Pará. Ciência Animal Brasileira, v.20, p.1-10, 2019. Available from: $<$ https://www.scielo.br/scielo.php?script=sci arttext\&pid=S1809-68912019000100303\&tlng=pt $>$. Accessed: Jun. 23, 2019. doi: 10.1590/1809-6891v20e-33566.

DE FREITAS, E. et al. Transmission of Leishmania infantum via blood transfusion in dogs: potential for infection and importance of clinical factors. Veterinary parasitology, v.137, n.1-2, p.159-167, 2006. Available from: <https://www.sciencedirect.com/science/ article/abs/pii/S0304401705006035?via\%3Dihub>. Accessed: Jun. 23, 2019. doi: 10.1016/j.vetpar.2005.12.011.

DUARTE, P. O. et al. Serological and molecular detection of Neospora caninum and Toxoplasma gondii in human umbilical cord blood and placental tissue samples. Scientific Reports, v.10, n.1, p.9043, 2020. Available from: $<$ https://www.nature.com/articles/s41598-020-659911>. Accessed: Jun. 23, 2019. doi: 10.1038/s41598-020-65991-1.

FURTADO, M. M. et al. Serosurvey of smooth Brucella, Leptospira spp. and Toxoplasma gondii in free-ranging jaguars (Panthera onca) and domestic animals from Brazil. PloS One, v.10, n.11, p.e0143816, 2015. Available from: <https://journals. plos.org/plosone/article?id=10.1371/journal.pone.0143816>. Accessed: Jun. 23, 2019. doi: 10.1371/journal.pone.0143816.

GARCIA, J. L. et al. Soroepidemiology of toxoplasmosis in cats and dogs drom rural properties of Jaguapitã county, Paraná state, Brazil. Ciência Rural, v.29, p.99-104, 1999. Available from: $<$ https://www.scielo.br/scielo.php?script=sci arttext\&pid=S0103$84781999000100018 \& \operatorname{lng}=$ pt\&tlng=pt $>$. Accessed: Jun. 23, 2019. doi: $10.1590 / \mathrm{S} 0103-84781999000100018$.

JOOB, B.; WIWANITKIT, V. Seroprevalence of Toxoplasma gondii in dogs and relationship to background temperature and humidity; a summative analysis. Acta Persica Pathophysiologica, v.4, p.e07, 2019. Available from: <http://nrsjournal.com/index. php/APP/article/viewFile/446/445>. Accessed: Jun. 23, 2019.

LINDSAY, D. S. et al. Mechanical transmission of Toxoplasma gondii oocysts by dogs. Veterinary Parasitology, v.73, n.1-
2, p.27-33, 1997. Available from: <https:/www.sciencedirect. com/science/article/abs/pii/S0304401797000484?via\%3Dihub>. Accessed: Jun. 23, 2019. doi: 10.1016/s0304-4017(97)00048-4.

LOPES, P. M. et al. Seroprevalence and risk factors associated with visceral leishmaniasis in dogs in Jaciara, State of Mato Grosso. Revista da Sociedade Brasileira de Medicina Tropical, v.47, n.6, p.791-795. Available from: <https:/www.scielo.br/scielo. php?script=sci_arttext\&pid=S0037-86822014000600791\&lng= en\&tlng=en>. Accessed: Jun. 23, 2019. doi: 10.1590/0037-86820027-2014

MACHACOVA, T. et al. Seroprevalence and risk factors of infections with Neospora caninum and Toxoplasma gondii in hunting dogs from Campania region, southern Italy. Folia Parasitologica (Praha), v.63, p.12, 2016. Available from: <http:// folia.paru.cas.cz/artkey/fol-201601-0012_seroprevalence and_risk_factors_of_infections_with_neospora_caninum_and_ toxoplasma_gondii_in_hunting_dogs_from.php $>$. Accessed: Jun. 23, 2019. doi: $10.14411 /$ fp.2016.012.

MACHADO, F.P. et al. Seroprevalence of anti-Toxoplasma gondii antibodies in wild boars (Sus scrofa), hunting dogs, and hunters of Brazil. PloS One, v.14, n.10, p.e0223474, 2019. Available from: $<$ https://journals.plos.org/plosone/article?id=10.1371/journal. pone.0223474>. Accessed: Jun. 23, 2019. doi: 10.1371/journal. pone. 0223474 .

MATTOS JR, D. G. et al. Clinical and laboratorial aspects of seropositive dogs to leishmaniosis. Arquivo Brasileiro de Medicina Veterinária e Zootecnia, v.56, n.1, p.119122, 2004. Available from: < https://www.scielo.br/scielo. php script $=$ sci arttext\&pid $=$ S0102-09352004000100019\&ln $\mathrm{g}=\mathrm{pt} \& \mathrm{t} \operatorname{lng}=\mathrm{pt}>$. Accessed: Jun. 23, 2019. doi: 10.1590/S010209352004000100019.

NAUCKE, T. J.; LORENTZ, S. First report of venereal and vertical transmission of canine leishmaniosis from naturally infected dogs in Germany. Parasites \& Vectors, v.5, p.67, 2012. Available from: <https://parasitesandvectors.biomedcentral.com/ articles/10.1186/1756-3305-5-67>. Accessed: Jun. 23, 2019. doi: $10.1186 / 1756-3305-5-67$.

ORR, B. et al. The welfare of pig-hunting dogs in Australia. Animals, v.9, n.853, p.1-14, 2019. Available from: <https://www. mdpi.com/2076-2615/9/10/853>. Accessed: Jun. 23, 2019. doi: 10.3390/ani9100853.

SÁNCHEZ, G. F. et al. Determination and correlation of antiNeospora caninum antibodies in dogs and cattle from Mexico. The Canadian Journal of Veterinary Research, v.67, n.2, p.142$145,2003$.

SORTE, E. C. B. et al. Serological and molecular detection of Toxoplasma gondii in dogs of urban and rural areas of Cuiaba, Mato Grosso. Semina: Ciências Agrárias, v.6, n.6, p.3705-3712, 2015. Available from: <http://www.uel.br/revistas/uel/index.php/ semagrarias/article/view/19209>. Accessed: Jun. 23, 2019. doi: 10.5433/1679-0359.2015v36n6p3705 